Bangladesh J. Plant Taxon. 23(2): 259-260, 2016 (December)

(C) 2016 Bangladesh Association of Plant Taxonomists

\title{
A NEW COMBINATION IN THE GENUS DIPLACRUM R. BR. (CYPERACEAE) FROM INDIA
}

\author{
K. Chandramohan ${ }^{1}$ \\ Botanical Survey of India, Deccan Regional Centre, Hyderabad-500 048, India
}

Keywords: Diplacrum; New combination; Scleria poklei; Sedge.

The genus Diplacrum R. Br. (1810) is distributed in tropical and subtropical regions of America, Africa, Asia, Australia and Lesser Sunda Islands and represented by eight (Govaerts and Simpson, 2007) to nine (www.theplantlist.org) species.The genus was described by Robert Brown (1810: 240) based on its two glumes which tightly enclose the nutlet and shed with it, nature of female spikelets and their distinctive facies. Later, the genus was merged in Scleria P. Bergius and treated in a separate section Diplacrum (Bentham, 1878; Clarke, 1894; Kern, 1961, Rao and Verma, 1982; Wadoodkhan, 1999). However, Simpson and Koyama (1998) and Govaerts and Simpson (2007) reinstated Robert Brown's Diplacrum as a genus. Recently, the distinction of Diplacrum from Scleria as a genus is further corroborated based on three DNA markers (Bauters et al., 2016). Diplacrum, accordingly finds place in the tribe Bisboeckelereae (Bauters in Bauters et al., 2016). In Indian floras, three species of Scleria, namely S. caricina (R.Br.) Benth., Scleria poklei Wad. Khan and Scleria africana Benth. are kept under the sections Diplacrum R. Br. and Sphaeropus (Boeck.) respectively by Dey and Prasanna (2015). Of these, one was originally described as Diplacrum caricinum R. Br. Another (S. africana Benth.) was also transferred to the genus Diplacrum. In the third species, S. poklei, nuts are hidden by glumes and falls off together which so far known from Maharashtra, India, needs to be transferred and it is being done here under.

Diplacrum poklei (Wad. Khan) Chandramohan, comb.nov.

Basionym: Scleria poklei Wad.Khan in J. Econ.Taxon. Bot. 22(3): 559, t.2. 1998 [publ. 1999], as 'pokelii'.

Type: India, Maharashtra, Gadchiroli district: Laheri road, Wadoodkhan4703 (Holotype: CAL-Acc. no. 4703-a!; Isotype: BSI-Acc. no.4703b-d!).

Note: Diplacrum poklei is endemic to Maharashtra, India.

\section{Key to the species of Diplacrum in India}

1. Glumes of nut bearing spikelets to expose the nuts 3-nerved, persistent on rachilla; nuts $0.4-0.5 \mathrm{~mm}$ long, ellipsoid, deciduous alone, acute, glabrous.

D. africana

- Glumes of nut bearing spikelets tightly clasping, many nerved, falling together with nut; nuts $0.7-1.0 \mathrm{~mm}$ long, subglobose or depressed globose, obtuse, pubescent at apex.

2. Glumes twice or more longer than the invested nut, spongious or cellularly thickened with in upper half; nuts ca. $1 \mathrm{~mm}$ long, densely hispidulous.

D. caricina

- Glumes as long as invested nuts, cellular but not thickened with in upper half; nuts 0.7-0.8 $\mathrm{mm}$, sparsely hispidulous at apex.

D. poklei

${ }^{1}$ E-mail: kolaganicm@gmail.com 


\section{Acknowledgements}

I am thankful to Dr. P. Singh, Director, Botanical Survey of India, Dr. M. Ahmedullah, Scientist In-charge, Botanical Survey of India, Deccan Regional Centre, Hyderabad and Head, Dept. of Botany, Osmania University, Hyderabad for facilities. I am also thankful to Prof. P. Ramachandra Reddy, Dr. L. Rasingam and Dr. Sangita Dey for encouragement; permission and logistic support provided by PCCF (WL) and Officials of Odisha State Forest department are gratefully acknowledged.

\section{References}

Bauters, K., Asselman, P., Simpson, D.A., Muasya, A.M., Goetghebeur. P. \& Larridon, I. 2016. Phylogenetics, ancestral state reconstruction, and a new infrageneric classification of Scleria (Cyperaceae) based on three DNA markers. Taxon. 65: 444-466.

Bentham, G. 1878. Scleria. In: Bentham, G. (Ed.), Flora Australiensis: A Description of the Plants of the Australian Territory 7: 425-427. L. Reeve \& Co, London. http://dx.doi.org/10.5962/bhl.title.16515

Brown, R. 1810. Novae Cyperaceae. Prodromus Florae Novae Hollandiaeet Insulae Van-Dieman. London.

Clarke, C.B. 1894. Cyperaceae. In: Hooker, J.D. (Ed.) Flora of British India 6: 635-680. L. Reeve \& Co, London.

Dey, Sangita and Prasanna, P.V. 2015. Cyperaceae: Mapaniodeae; Cyperaceae: Cyperoideae, Tribe Schoeneae and Sclerieae. In: Singh, P. \& Dey, Sangita (Eds), Fsc. Fl. India 27 Botanical Survey of India, Kolkata, pp. 61-65 \& 90-92.

Govaerts, R. and Simpson, D.A. 2007. World Checklist of Cyperaceae. Sedges. Kew Publishing, Royal Botanical Gardens, Kew, pp. 413-14.

Kern, J.H. 1961. Florae Malesianae Procursores XXX. The genus Scleria in Malaysia. Blumea 11: 140-218.

Rao, A.S. and Verma, D.M. 1982. Cyperaceae of North East India. pp. 22-26. Calcutta.

Simpson D. \& T. Koyama 1998.Cyperaceae in Fl. Thailand 6(4): 426-447.

Wadoodkhan, M.A. 1998 (publ. 1999). Novelties in Cyperaceae of Maharashtra. J. Econ. Taxon. Bot. 22(3): 555-561. 